\title{
Runoff and Sediment Yield Estimation by SWAT Model: Review and Outlook
}

\author{
Vasantgouda Roti", P.S. Kashyap, Anilkumar, R.K. Srivastava and Harish Chandra
}

Govind Ballabh Pant University of Agriculture and Technology, (GBPUA\&T), Pantnagar, India

*Corresponding author

\section{A B S T R A C T}

Keywords

Modeling, SWAT model, Runoff, Sediment yield calibration and validation

Article Info

Accepted: 06 September 2018 Available Online: 10 October 2018
For accurate and easy estimation of runoff and sediment yield can be done by using physical based continuous hydrological model. Among the many hydrological model Soil and Water Assessment Tool (SWAT) is the more promising model for simulations in predominant agricultural watershed. Moreover the model is better in assessing both spatial and temporal variability of the hydrological process under very large watershed. The present paper provides the methodology used by the SWAT for calculation of runoff and sediment yield. During model setup input data required by the model, sensitivity parameter analysis, calibration and validation are discussed in detail. In sensitivity analysis in case of stream flow simulation, parameters such as initial SCS Runoff curve number for moisture condition II (CN2), Base flow alpha factor (ALPHA_BF), Groundwater delay time (GW_DELAY), Threshold depth of water in the shallow aquifer required for return flow to occur (GWQMN) and Surface runoff lag coefficient (SURLAG), etc., which significantly impact the discharge simulation.

\section{Introduction}

The availability of accurate runoff and sediment yield data is scarcely in India. So, there is necessitates the research in simulation of processes like runoff and transport of sediment from watersheds through hydrological modelling (Zade et al., 2014).

The hydrological models help in understanding the hydrological processes and also for assessing the impact of human activities on environment and agricultural production. This will help to suggest the proper erosion control measures to erosion.
There have been several hydrological models developed to estimate runoff and soil loss from a watershed namely: USLE (Wischmeier and Smith, 1960), MUSLE (Williams, 1975), RUSLE (Knneth, 1991), ANSWERS (Area Non-point Source Watershed Environment Response Simulation) (Beasley, 1980), AGNPS (Agriculture Non-point Pollution Source) (Young et al., 1989), SWAT (Soil and Water Analysis Tool) (Arnold et al., 1993), WEPP (Water Erosion Prediction Programme) (laflen et al., 1991) etc., are few among the models. The applicability of these models had been evaluated under different conditions from different researchers in different part of 
the world and revealed that SWAT model is more accurate than the AGNPS, ANSWEAR, HSPF (Hydrological Simulation ProgramFortran) (Mishra et al., 2008; Matamoros et al., 2005 and Ogwa et al., 2012). The WEPP model is accurate than the SWAT (Ogwa et al., 2012) but it overestimates sediment yield in large watershed area (Maalim et al., 2013) but SWAT is accurate in both small (Gitau et al., 2008) and large areas and also it is better in assessing both spatial and temporal variability of the hydrological process (Green et al., 2006, Borah and Bera, 2003, and Rossi et al., 2009). So, hydrological model SWAT is selected for the present study.

\section{Over view of SWAT}

The SWAT (Soil and Water Assessment Tool) is a public domain model jointly developed by United State Department of Agriculture, Agricultural Research Service (USDAARS) and Texas A \& M University System (Arnold et al., 1998). The SWAT model is a physically based, deterministic, continuous time and long term simulation model (Arnold et al., 1995). The main aim of the model is to predict the impact of land management practices on water, sediment and agricultural chemical yields in large ungauged basins. The merits of the model are as follows (Arnold et al., 1998).

\section{Recommended methodology}

In SWAT, modelling purpose a watershed will be partitioned into a number of sub watersheds or sub basins and within the sub basin that the area comprises of unique land cover, soil and slope combinations are will be considered as one Hydrologic Response Unit (HRU). Similarly classify the whole sub basin into several HRUs. This is because to increases the accuracy in flow prediction and provides a much better physical description of the water balance.
In SWAT hydrologic cycle is simulated by the principal of water balance equation

$$
S W_{f}=S W_{i}+\sum_{i=1}^{t}\left(R_{d a y}-E T_{a}-Q_{\text {suf }}-W_{p}-Q_{r}\right)
$$

Where, $\mathrm{SW}_{\mathrm{t}}$ - final soil water content in the soil layer $(\mathrm{mm}), \mathrm{SW}_{\mathrm{i}}$ - initial soil water content of the soil on day $\mathrm{i}(\mathrm{mm}), \mathrm{t}$ - time (days), $\mathrm{R}_{\text {day }}$ - amount of precipitation on day $\mathrm{i}$ (mm), $\mathrm{ET}_{\mathrm{a}}$ - amount of evapotranspiration on day $\mathrm{i}(\mathrm{mm}), \mathrm{Q}_{\text {surf }}$ - amount of surface runoff on day $\mathrm{i}(\mathrm{mm}), \mathrm{W}_{\mathrm{p}}$ - amount of water percolating to the underlying soil layer on day i $(\mathrm{mm}) \mathrm{Q}_{\mathrm{r}}$ amount of return flow on day $\mathrm{i}(\mathrm{mm})$.

Simulation of the hydrology of a watershed can be separated into two major divisions. The first division is the land phase of the hydrologic cycle. In land phase of the hydrologic cycle controls the amount of water, sediment, nutrient and pesticide loadings to the main channel in each sub basin. The second division is the water or routing phase of the hydrologic cycle. In routing phase define the movement of water, sediments, etc. through the channel network of the watershed to the outlet.

\section{Data required for the SWAT model}

Soil map, land use/cover map and DEM are basic map use as input in the SWAT tool. Meteorological data are rainfall amount, maximum and minimum temperature, wind speed, solar intensity, Dew point are required. Hydrological data includes daily runoff volume, flow velocity and sediment yield, physical and chemical properties of soil are required for the analysis.

Estimation of surface runoff: The most commonly used method in SWAT model for estimating surface runoff is SCS curve number method (SCS, 1972). 
$Q_{\text {surf }}=\frac{\left(R_{d a y}-I_{a}\right)^{2}}{\left(R_{d a y}-I_{a}+S\right)}$

Where, $\mathrm{Q}_{\text {surf }}$ - accumulated runoff or rainfall excess $(\mathrm{mm}), R_{\text {day }}$ - rainfall depth for the day $(\mathrm{mm}), \mathrm{I}_{\mathrm{a}}$ - initial abstractions which includes surface storage, interception and infiltration prior to runoff (mm), S - Retention parameter (mm).

The retention parameter varies spatially due to changes in soil water content. The retention parameter is defined as:

$$
S=25.4+\left[\frac{100}{C N}-10\right\rceil
$$

Where, $\mathrm{CN}$ - curve number for the day, the constant 25.4, in equation used to convert the gives $\mathrm{S}$ in to $\mathrm{mm}$.

The SCS curve number depends upon soil type, land use/cover and Antecedent Moisture Conditions (AMC). The hydrologic soils are classified as A, B, C and D depends upon the infiltration and other characteristics. As the order increasing from $A$ to $D$, the runoff potential increases and the infiltration rate decreases.

Group A have the lowest and group D have the highest runoff potential. Antecedent Moisture Conditions (AMC) refers the moisture content present in the soil at the beginning of rainfall runoff event. Antecedent Moisture Conditions (AMC) classified based upon the soil moisture content: AMC-I (wilting point), AMC-II (average moisture and AMC-III (field capacity). SWAT uses AMC-II for $\mathrm{CN}$ estimation. The values of curve number for different land use conditions and hydrologic soil groups are given by by Dhruva Narayana, (1993), this gives the curve number for antecedent moisture condition (AMC)-II i.e., for average condition.
Once SWAT decides the loadings of water and sediment to the main channel, the loadings are routed through the stream network of watershed using Muskingum routing method (Chow et al., 1988).

Erosion and sediment yield estimation from SWAT for each sub basin using Modified Universal Soil Loss Equation (MUSLE), Williams (1975) given below,

Sed $=11.8 *\left(Q * q_{p} * A_{H R U}\right)^{0.56} * K * C * P * L S * C_{f}$

Where, Sed - sediment generation (metric tonne), Q - Surface runoff $(\mathrm{mm}), \mathrm{q}_{\mathrm{p}}$ - peak runoff rate $\left(\mathrm{m}^{3} / \mathrm{s}^{-1}\right), \mathrm{A}_{\mathrm{HRU}}-\mathrm{HRU}$ area (ha), $\mathrm{K}$ soil erodibility factor, $\mathrm{C}$ - cover and management factor, $\mathrm{P}$ - support practice factor, LS - topographic factor, $\mathrm{C}_{\mathrm{f}}$ - coase fragment factor

Sediment generation is calculated individually for each HRU and then summed to determine total sub-basin (Arnold et al., 1998).

Surface runoff $(Q)$ is directly taken from the runoff calculation and peak runoff rate $q_{p}$ is calculated with a modified rational method, the rate of runoff will increase until the time of concentration, $t=t_{\text {conc }}$, when the entire subbasin area is contributing to flow at the outlet.

The rational formula is

$q_{p}=\frac{C * i * \text { Area }}{3.6}$

Where, $q_{p}$ - peak runoff rate $\left(\mathrm{m}^{3} / \mathrm{s}^{-1}\right), C$ runoff coefficient, $I$ - rainfall intensity $(\mathrm{mm} / \mathrm{h})$, Area - sub-basin area $\left(\mathrm{km}^{2}\right)$ and 3.6 is a unit conversion factor (Neitsch et al., 2005).

$i$ is calculated from the maximum half hour rainfall for a month, which is provided to the model in the weather database. 
In land component, SWAT keep tracks the particle size distribution of eroded sediments and routes them through ponds, channels, and surface water bodies.

The sediment yield in the land is lagged and routed through grassed waterway, vegetative filter strips and ponds, if available, then reaching the stream channel. Thus, the sediment yield reaching the stream channel is the sum of total sediment yield calculated by MUSLE minus the lag, and the sediment trapped in grassed waterway, vegetative filter strips and/or ponds (Neitsch et al., 2011).

Sediment routing is the function of peak flow rate and mean daily flow. When the watershed was delineated into smaller sub basin, each sub basins has at least one main routing reach. Therefore, the sediment from upland sub basins is routed through these reaches and then added to downstream reaches. To do this, SWAT uses the simplified version of Bagnold equation (Bagnold, 1977) and the maximum amount of sediment that can be transported from a reach segment is a function of the peak channel velocity.

conc sed ,ch, mx $=C_{s p} * V_{c h, p k^{s p e x p}}$ (6)

Where, conc $_{\text {sed,ch,mx }}$ - maximum concentration of sediment that can be transported by water (ton $/ \mathrm{m}^{3}$ or $\mathrm{kg} / \mathrm{l}$ ), $C_{s p}$ and $s p$ exp - coefficient and exponent of the equation defined by the user, and $\mathrm{V}_{c h, p k}$ - peak channel velocity $(\mathrm{m} / \mathrm{s})$. The exponent $s p$ exp normally varies from between 1.0 and 2.0 and was set at 1.5 in the original Bagnold stream power equation (Arnold et al., 1995).

$V_{c h, p k}=\frac{q_{c h, p k}}{A_{c h}}$

Where, $\mathrm{q}_{c h, p k}$ - peak flow rate $\left(\mathrm{m}^{3} / \mathrm{s}\right)$ and $\mathrm{A}_{c h}$ cross-sectional area of flow in the channel $\left(\mathrm{m}^{2}\right)$ $q_{c h, p k}=p r f * q_{c h}$

Where, $\operatorname{Prf}$ - peak rate adjustment factor, and $\mathrm{q}_{c h}$ - average rate of flow $\left(\mathrm{m}^{3} / \mathrm{s}\right)$.

The routing in the river reach starts off by comparing the maximum concentration of sediment above to the concentration of sediment in the reach at the beginning of the time step, conc $_{\text {sed ch } i}$. If conc $\mathrm{c}_{\text {sed, } c h, i}>$ conc $_{\text {sed, }}$ $c h, m x$ deposition is the dominant process in the reach segment and the net amount of sediment deposited is calculated as in equation (9) below.

sed dep $=($ conc sed,ch, $i-\operatorname{conc}$ sed $, c h, m x) * V_{c h}$

On the other hand, if conc $_{\text {sed, }, c h, i}<$ conc $_{\text {sed, }}$, $m x$ degradation is the dominant process in the reach segment and the net amount of sediment re-entrained is calculated as in equation (10) below.

sed $\operatorname{deg}=($ conc sed, $c h, m x-\operatorname{conc}$ sed, $, c h, i) V_{c h} * K_{C H} * C_{C H}$

The channel erodibility factor is conceptually similar to the soil erodibility factor used in the USLE equation. Channel erodibility is a function of properties of the bed or bank materials. The detail discussion of factors is found in Neitsch et al., (2011). In general, values for channel erodibility are an order of magnitude smaller than values for soil erodibility.

The channel cover factor can be defined as the ratio of degradation from a channel with a specified vegetation cover to the corresponding degradation from a channel with no vegetation cover.

The vegetation affects degradation by reducing the stream velocity, and consequently its erosive power, near the bed surface (Neitsch et al., 2011). 
Table.1 List of initially selected parameters used in runoff sensitivity analysis

\begin{tabular}{|c|c|c|c|}
\hline S. No. & Parameter & Description of Parameters & Types of parameter \\
\hline 1 & SOL_K & Saturated hydraulic conductivity $(\mathrm{mm} / \mathrm{hr})$ & Soil water \\
\hline 2 & SLP & Average slope steepness & Geomorphology \\
\hline 3 & RCHRG_DP & Deep aquifer percolation fraction & Ground water \\
\hline 4 & $\mathrm{CN}_{2}$ & SCS runoff curve number for AMC-II & Surface runoff \\
\hline 5 & ALPHA_BF & Base flow alpha factor & Ground water \\
\hline 6 & GW_DELAY & Groundwater delay & Ground water \\
\hline 7 & SOL_BD & Moist bulk density & Soil water \\
\hline 8 & CH_N1 & $\begin{array}{l}\text { Manning's " } n \text { " value for the tributary } \\
\text { Channel }\end{array}$ & Channel process \\
\hline 9 & ESCO & Soil evaporation compensation factor & Evapotranspiration \\
\hline 10 & SURLAG & Surface runoff lag time & Surface runoff \\
\hline 11 & GW_REVAP & Groundwater revap coefficient & Ground water \\
\hline 12 & CH_K1 & $\begin{array}{l}\text { Effective hydraulic conductivity in the } \\
\text { tributary channel }\end{array}$ & Channel process \\
\hline 13 & GW_SPYLD & Specific yield of the shallow acquifer & Ground water \\
\hline 14 & CH_K2 & $\begin{array}{l}\text { Effective hydraulic conductivity in the main } \\
\text { channel }\end{array}$ & Channel process \\
\hline 15 & SOL_AWC & Available water content of soil & Soil water \\
\hline 16 & SLSUBBSN & Average slope length & Geomorphology \\
\hline 17 & BLAI & Maximum potential leaf area index & Evapotranspiration \\
\hline 18 & SOL_ALB & Moist soil albedo & Soil water \\
\hline 19 & CANMX & Maximum canopy storage & Surface runoff \\
\hline 20 & EPCO & Plant uptake compensation factor & Evapotranspiration \\
\hline
\end{tabular}

Table.2 List of initially selected parameters used in sediment yield sensitivity analysis

\begin{tabular}{|c|c|c|c|}
\hline S. No. & Parameter & Description of Parameters & Types of parameter \\
\hline 1 & SPEXP & $\begin{array}{l}\text { Exponential parameter for calculating } \\
\text { sediment re-entrainment in the channel } \\
\text { sediment routing }\end{array}$ & Channel \\
\hline 2 & $\mathrm{CH}_{-} \mathrm{N}_{2}$ & Manning's 'n' value for the main channel & Channel \\
\hline 3 & SLSUBBSN & Average slope length & Geomorphology \\
\hline 4 & CH_S $\mathrm{S}_{2}$ & Average slope of main channel & Channel \\
\hline 5 & OV_N & Manning's ' $n$ ' value for the overland flow & Surface runoff \\
\hline 6 & HRU_SLP & Average slope steepness & Surface runoff \\
\hline 7 & SPCON & $\begin{array}{l}\text { Linear amount of sediment that can be re- } \\
\text { entrainment during channel sediment routing }\end{array}$ & Channel \\
\hline 8 & $\mathrm{CH} \_\mathrm{K}_{2}$ & $\begin{array}{l}\text { Effective hydraulic conductivity in the main } \\
\text { channel }\end{array}$ & Channel process \\
\hline 9 & PRF & Peak rate adjustment factor & Channel \\
\hline 10 & CH_W 2 & Average width of main channel & Channel \\
\hline 11 & CH_D & Average depth of main channel & Channel \\
\hline 12 & CH_L2 & Average length of main channel & Channel \\
\hline
\end{tabular}


Once the amount of deposition and degradation has been calculated, the final amount of sediment in the reach is determined by equation

sed $c h=\operatorname{sed}_{c h, i}-\operatorname{sed}_{d e p}+\operatorname{sed}_{\mathrm{deg}}$

Thus, the amount of sediment transported out of the reach is calculated using equation

sed ${ }_{\text {out }}=\operatorname{sed}_{c h} \frac{V_{\text {out }}}{V_{c h}}$

Where, $\operatorname{sed}_{\text {out }}$ - amount of sediment transported out of the reach (metric tons), Vout - volume of outflow during the time step $\left(\mathrm{m}^{3}\right)$.

\section{Sensitivity analysis, calibration and validation of SWAT}

The first step in the calibration and validation process in SWAT is the determination of the most sensitive parameters for a given watershed or sub-watershed because SWAT is a complex model with many parameters that makes manual calibration difficult (Abbaspour, 2013). Sensitivity analysis helps to determine the relative ranking of which parameters most affect the output variance due to input variability (Van Griensven et al., 2002), it allow the possible reduction in the number of parameter that must be calibrated thereby reducing the computational time required for model calibration and also reduces uncertainty and provides parameter estimation guidance for the calibration. Table 1 and 2 are shows initial parameters used in the sensitivity analysis for runoff flow and sediment yield calibration.

Calibration is the process whereby selected parameters and variables of the model are adjusted to make the model output match with the observed results. Calibration is considered to be necessary because there may be uncertainties in the model input due to spatial variability, budget constraints and access difficulties (Lenhart et al., 2002). SWAT CUP is a computer programme for calibration of SWAT models. Within the SWAT CUP package SUFI-2 (Sequential Uncertainty Fitting Version 2 programme) used for model calibration process in the present study.

Model validation is the process of re-running the simulation, using a different time-series for input data, without changing any parameter values which may have been adjusted during calibration. In order to utilize the calibrated model for estimating the effectiveness of future potential management practices, the model was tested against an independent set of measured data. As the model predictive capability was demonstrated as being reasonable in both the calibration and validation phases, the model was used for future predictions under different management scenarios.

\section{Model evaluation}

The model evaluation procedure included calibration and validation. A number of test statistics and techniques can be used for model evaluation and to test the goodness-offit of the model to simulate reality. The performance of both the models will be evaluated on the basis of test criteria and statistical indices, popular are Nash-Sutcliffe efficiency $\left(\mathrm{E}_{\mathrm{NS}}\right)$ (Nash and Sutcliffe, 1970), Coefficient of Determination $\left(\mathrm{R}^{2}\right)$ (Moriasi et al., 2007), Root Mean Square Error (RMSE), Percent bias (PBIAS) (Gupta et al., 1999).

The SWAT model estimate runoff and sediment in land phase and routing phase separately these increases the accuracy of the model simulation. These work on the principle of water balance. The runoff in land phase estimated by using SCS curve number method and routing phase Muskigum method 
is most popular methods used in the SWAT model. The sediment yield is estimated from MUSLE equation. The SWAT model is not only for estimation of runoff and sediment yield it is also useful to know the impact of agriculture practice and land use on runoff and sediment.

\section{Acknowledgement}

The facilities and financial support provided by the University of GBPUA\&T Pantnagar are sincerely acknowledge by the authors.

\section{References}

Abbaspour, K. C. 2013. SWAT-CUP 2012: SWAT calibration and uncertainty programs-A

Arnold, J. G., Allen, P. M. and Bernhardt, G. 1993. A comprehensive surfacegroundwater flow model. Journal of hydrology, 142(1):47-69.

Arnold, J. G., R. Srinivasan, R. S. Muttaih and J. R. Williamns. 1998. Large area hydrologic modelling assessment Part I model development. Journal of American Water resource Assoc., 34:73-89.

Arnold, J. G., Williams, J. R., and Maidment, D. R. 1995. Continuous-time water and sediment-routing model for large basins. Journal of Hydraulic Engineering, 121(2): 171-183.

Bagnold, R. A. 1977. Bed load transport by natural rivers. Water resources research, 13(2):303-312.

Beasley, D. B., Huggins, L. F. and Monke, E. J. 1980. ANSWEARS: a model for watershed planning. Transactions American Society of Agricultural Engineers (ASAE), 23(4):938-944.

Borah, D. K. and Bera, M. 2003. Watershed scale hydrologic and nonpoint source pollution models: review of mathematics bases. Transactions
American Society of Agricultural Engineers (ASAE), 46(6):1553-1566.

Dhruva Narayana, V. V. 1993. Soil and Water Conservation Research in India. ICAR Krishi Anusandhan Bhavan, Pusa, New Delhi, India.

Gitau, M. W., Gburek, W. J., and Bishop, P. L. 2008. Use of the SWAT model to quantify water quality effects of agricultural BMPs at the farm-scale level. Transactions American Society of Agricultural Engineers (ASAE), 51(6):1925-1936.

Green, C. H., Tomer, M. D., Di Luzio, M. and Arnold, J. G. 2006. Hydrologic evaluation of the soil and water assessment tool for a large tile-drained watershed in Iowa. Transactions American Society of Agricultural Engineers (ASAE), 49(2):413-422.

Gupta, H., Sorooshian, S. and Yapo, P. 1999. Status of Automatic Calibration for Hydrologic Models: Comparison with Multilevel Expert Calibration. International Journal of Hydrologic Engineering, 4(2):135-143.

Knneth, G. R., Foster, g. R., Weesies and Porter, J. P. 1991. Revised Universal soil loss equation. Journal of soil and water conservation, 46:30-33.

Laflen, J. M., Lane, J. L. and foster, G. R. 1991. WEPP- a new generation of erosion prediction technology. Journal of soil water conservation, 46(1):34-38.

Lenhart, T., Eckhardt, K., Fohrer, N. and Frede, H. G. 2002. Comparison of two different approaches of sensitivity analysis. Physics and Chemistry of the Earth, 27:645-654.

Maalim, F. K., Melesse, A. M., Belmont P. and Gran, K. B. 2013. Modeling the impact of land use changes on runoff and sediment yield in the Le Sueur watershed, Minnesota using GeoWEPP. Catena, 107:35-45. 
Matamoros, D. E., Guzman, J. Bonni and Vanrolleghem. 2005. AGNPS and SWAT model calibration for hydrologic modelling of an Ecuadorian river basin under data scarcity-IWA publishing, London UK.

Mishra, A., Kar. S. and Pandey, A. C. 2008. Comparison of SWAT with HSPF model in predicting hydrological processes of a small watershed. Journal of Agricultural Engineering, 45(4).

Moriasi, D. N. Arnold, J. G. Van Liew, M. W., Bingner, R. L., Harmel, R. D. and Veith T. L. 2007. Model evaluation guidelines for systematic quantification of accuracy in watershed simulations. American Society of Agricultural and Biological Engineers, 50(3):885-900.

Nash, J. E. and Sutcliffe, J. V. 1970. River flow forecasting through conceptual models: Part-I A discussion of principles. Journal of Hydrology, 10(3):282-290.

Neitsch, S. L., Arnold, J. G. and Kiniry, J. R. 2005. Soil and Water Analysis tool theoretical documentation, version 2000 $(\mathrm{J} / \mathrm{OL})$.

Neitsch, S. L., Arnold, J. G., Kiniry, J. R., and Williams, J. R. 2011. Soil and water assessment tool theoretical documentation version 2009. Texas Water Resources Institute.

Rossi, C. G., Srinivasan, R., Jirayoot, K., Le Due, T., Souvannabouth, P., Binh, N. and Gassman, P. W. 2009. Hydrological evaluation of the lower Mekong river basin with the soil and water assessment tool model. International agricultural engineering Journal, 18(1):1-13.

Van Griensven, A., Francos, A. and Bauwens, W. 2002. Sensitivity analysis and auto calibration of an integral dynamic model for river water quality. Water Science Technology, 45:325-332.

Williams, J. R. 1975. Sediment yield prediction with universal equation using runoff energy factor. Proceedings of the sediment Yield Workshop, USDA Sedimentation Laboratory, Oxford, Mississippi.

Wischmeier, W. H. and Smith. D. D. 1960. A universal soil-loss equation to guide conservation farm planning. Transactions $7^{\text {th }}$ International Congress on Soil Science, 1:418-425.

Young, R. A., Onstad, C. A., Bosch, D. D. and Anderson, P. P. 1989. AGNPS: A Non-ponit Source Pollution model for evaluation agricultural watersheds. Journal of soil and water conservation, 44(2):168-173.

Zade, M., Ray, S. S., Dutta, S. and Panigrahy, S. 2014. Analysis of runoff pattern for all major basins of India derived using remote sensing data. Current Science, 88(8):1301-1305.

\section{How to cite this article:}

Vasantgouda Roti, P.S. Kashyap, Anilkumar, R.K. Srivastava and Harish Chandra. 2018. Runoff and Sediment Yield Estimation by SWAT Model: Review and Outlook. Int.J.Curr.Microbiol.App.Sci. 7(10): 879-886. doi: https://doi.org/10.20546/ijcmas.2018.710.097 